Bleiessig und mit Chlorzink auszuführen wäre. Die mit Hypobromit erhaltenen Zahlen sollen den Gesammtstickstofi, daun diesen weniger Harnsäure, endlich den Gesammtstickstoff weniger Harnsäure und Kreatinin ergeben. J. Moitessier ${ }^{1}$ ) zeigt nun, dass einmal bei der geringen Menge Harnsäure und Kreatinin die entwickelte Gasmenge zu klein ausfällt, dass ferner weder die Ausfällung mit Bleiessig noch auch jene mit Chlorzink in der angegebenen Richtung verwendbar ist.

\title{
Eine Methode zur Bestimmung des Volumens der körperlichen
} Elemente des Blutes haben M. and L. Bleibtreu ${ }^{2}$ ) auf Pflïger's Anregung ausgearbeitet. Vermischt man defibrinirtes Blut in versuhiedenen Verhältnissen mit physiologischer Kochsalzlösung und lässt die Blutkörperchen sich absetzen, so kann aus dem Stickstoffgehalt oder dem specifischen Gewicht der überstehenden, klaren Flüssigkeit das Volumverhältniss von körperlichen Elementen und Serum ermittelt werden. Das Princip des ersteren Verfahrens ist folgendes. Bezeichnet $b_{1}$ die $\mathrm{zu}$ der Mischung verwendete Blutmenge, $\mathrm{s}_{1}$ das zugesetzte Volum Kochsalzlösung, $x$ den echten Bruch, mit welchem man das Blutvolum $b_{1}$ multipliciren muss, um das darin enthaltene Flüssigkeitsvolum zu erhalten, so beträgt die Gesammtmenge der Mischung $b_{1} x+s_{1}$. Verwendet man ein bestimmtes Volum dieser Kochsalz-Serum-Mischung zur Analyse z. B. $5 c c$, so sind darin $5 \frac{\mathrm{b}_{1} \mathrm{x}}{\mathrm{b}_{1} \mathrm{x}+\mathrm{s}_{1}} c c$ Serum enthalten, aus deren nach $\mathrm{Kj}$ eldahl sorgfältig bestimmtem Stickstoffgebalt sich durch Multiplication mit 6,25 der Gehalt an $\gg$ Eiweiss « $e_{1}$ ergibt. In einem Versuch mit anders gewählter Verdünnung findet man in gleicher Weise für 5 cc der Mischung $=5 \frac{\mathrm{b}_{2} \mathrm{x}}{\mathrm{b}_{2} \mathrm{x}+\mathrm{s}_{2}} c c$ Serum einen Eiweissgehalt $\mathrm{e}_{2}$.

Hieraus folgt, dass in $5 c c$ ursprünglichen Serums $e_{1} \frac{b_{1} x+s_{1}}{b_{1} x}$ beziehentlich $e_{2} \frac{b_{2} x+s_{2}}{b_{2} x} g$ Eiweiss enthalten sind, woraus fur $x$ die Gleichung folgt:

$$
x\left(e_{1}-e_{2}\right)=e_{2} \frac{s_{2}}{b_{2}}-e_{1} \frac{s_{1}}{b_{1}} .
$$

Die Berechnung wird sehr vereinfacht, wenn die Mischungen nach einfachem Verhältniss erfolgen. Die Verfasser messen 0,6 procentige Koch-

1) Bull. de la soc. chim. de Paris [3] 6, 907.

2) Pflüg er's Archiv f. d. ges. Physiologie 51, 151. 
salzlösung und Blut getrennt in Messkolben, und zwar im Verbältniss von $1: 4,1: 3,1: 2,1: 1,3: 4$, oder $1: 1,5$ ab, giessen beịde Flüssigkeiten in ein Becherglas und spülen mit dem Gemenge wiederholt die Messkölbchen aus. Die gleichmäfsig gemengte Flüssigkeit wird endlich in ein Kölbchen mit langem, nicht zu engem Hals gefüllt, wo sich im Hals das Absetzen rasch vollzieht. Das Abheben der Proben geschieht mit Pipetten.

Das Verfahren erfordert zum mindesten zwei Stickstoffbestimmungen. Grössere Sicherheit bietet die Untersuchung dreier verschiedener Mischungen, da sie eine doppelte Controle der Fehlergrösse gewährt.

Statt einer Probe verdünnten Blutes kann auch unverdünntes Serum genommen werden, für welchen Fall die obige Formel die einfachere Gestalt $\left(e_{0}-e_{1}\right) x=e_{1} \frac{s_{1}}{b_{1}}$ annimmt.

Die mitgetheilten, vorzugsweise an Pferdeblut ausgeführten Bestimmungen weisen, so weit sie sich unter einander controliren, eine genügende Uebereinstimmung aus. Die Differenzen betragen zumeist unter $2 \%$. Da dies trotz sehr verschiedenen Verdünnungsgrades der Fall ist, so muss angenommen werden, dass die Kochsalzlösung das Volumen der Blutkörperchen nicht merklich ändert. Bittersalzlösung jedoch bewirkt Schrumpfung der Blutkörperchen, weshalb auch die Versuche der Verfasser scheiterten, durch Verwendung dieses gerinnungshemmenden Salzes zu einer auf nicht defibrinirtes Blut anwendbaren Methode zu gelangen.

Die in's Ange gefasste Volumbestimmung lässt sich auch mit Hülfe zweier pyknometrischer Bestimmungen ausführen.

Werden $\mathrm{s} c c$ Kochsalzlösung mit b $c c$ defibrinirten Blutes gemischt und wird das specifische Gewicht der Mischung nach Absetzen der Blutkörperchen gleich $\delta$ ermittelt, ist ferner $\delta_{\mathbf{o}}$ das specifische Gewicht des Serums und $\mathrm{k}$ jenes der Kochsalzlösung, so zeigt eine einfache Ueberlegung, dass $\mathrm{x}=\frac{\mathrm{s}}{\mathrm{b}} \cdot \frac{\delta-\mathrm{k}}{\delta_{0}-\delta}$.

Das Verfahren gibt, wie aus den mitgetheilten Analysen hervorgeht, dieselben Werthe wie das Vorbeschriebene.

Für das Pferdeblut konnten M. und L. Bleibtreu noch weitere Vereinfachungen in Vorschlag bringen, welche von der Thatsache ausgehen, dass hier die Substanz der Blutkörperchen einen annähernd, constanten Stickstoffgehalt und annähernd gleiches specifisches Gewicht besitzen. In diesem Fall nämlich ist die Differenz, welche sich ergibt, 
wenn man den Eiweissprocentgehalt des Serums von jenem des defibrinirten Blutes abzieht, dem Volumen der Blutkörperchen annähernd proportional. Bezeichnet $\mathrm{E}$ den Eiweissgehalt des Gesammtbluts in Procenten, e jenen des Serums, so ist das Volum der Blutkörperchen $\mathrm{v}=(\mathrm{E}-\mathrm{e}) \mathrm{C}$ worin $\mathrm{C}$ eine Constante ist, die sich für Pferdeblut im Mittel zu 2,55 herausstellt. Die anf diesem Wege gefundenen Zahlen stehen den auf obigem Wege erhaltenen sehr nahe.

Das Spectrum des Methämoglobins zeigt, wie P. Dittrich ${ }^{1}$ ) in Uebereinstimmung mit $\operatorname{Araki}^{2}$ ) findet, nur zwei Absorptionsstreifen. Eine lösung der reinen Krystalle lässt bei Betrachtung in $1 \mathrm{~cm}$ dicker Schicht die rothen Strahlen selbst in einer Concentration von $3 \%$ bis zu einer Wellenlänge von etwa 660 durch. Dann beginnt die dem allgemein anerkannten Methämoglobinstreifen entsprechende Verdunkelung, deren Mitte auf $\lambda=632$ fällt. Von da ab nimmt die Absorption bis etwa $606 \mathrm{ab}$, bleibt dann bis D annähernd constant, um von da ab staffelförmig weiter zuzunehmen. Die nächste Verdunkelungsstufe, die etwa. bei 579 ihren Wendepunkt (oder ein geringes Maximum) hat, entspricht dem Absorptionsstreifen II der Autoren. Eine weitere Verdunkelungsstufe, bei etwa 540, tritt nicht als Streifen, sondern nur als Beginn einer stärkeren diffusen Absorption hervor, welche gleichmässig zunehmend den Rest des Spectrums einnimmt.

Die Streifen III und IV früherer Untersucher vermochte Dittrich in völlig von Oxyhämoglobin freien Lösungen nie zu finden. Die mit. dem Spectrophotometer gemessene Absorption ergab sich rechts von I durchweg als bedeutend.

Erst bei Lösungen unter $2 \%$ war die Aufhellung rechts von I wahrnehmbar: Der Streifen I blieb dann bis zu einer Concentration von $0,22 \%$ sichtbar. Bei $0,11 \%$ war er nicht mehr erkennbar. Der Streifen II tauchte bei etwa $2 \%$ auf, war bei $0,894 \%$ nur noch angedeutet, bei $0,447 \%$ nicht mehr erkennbar.

Ueber den Nachweis von Kohlenoxyd im Blut. Kohlenoxydblut wird nach H. Bertin-Sans und J. Moitessier ${ }^{3}$ ) durch Ferridcyankalium unter Freiwerden des Kohlenoxyds in Methämoglobin übergeführt.

1) Archiv f. experim. Pathol. u. Pharmakol. 29, 247.

2) Diese Zeitschrift 30, 112.

3) Comptes rendus 113, 210. 